\title{
Description of a new Psychodidae (Diptera) species from Estonia
}

\author{
Jukka Salmela \& Tero Piirainen
}

Salmela, J. \& Piirainen, T. 2005: Description of a new Psychodidae (Diptera) species from Estonia. — Entomol. Fennica 16: 301-304.

Lepimormia hemiboreale sp. n. (Diptera, Psychodidae) from Estonia, Saaremaa Island, is described. The description of the species is based on Malaise trap material collected from an eutrophic spring fen in Viidumäe Nature Reserve. Lepimormia hemiboreale sp. n. is quite similar to L. georgica (Wagner, 1981), L. sibirica Ježek, 1994 and L. vardarica (Krek, 1982) but the shape of aedeagus, subgenital and anal valves readily distinguish $L$. hemiboreale sp. n. from these. In addition to the new species, 13 moth fly species are reported for the first time from Estonia.

J. Salmela, Department of Bio- and Environmental Sciences, P. O. Box 35 (YA), FI-40014 University of Jyväskylä, Finland. E-mail: jueesalm@cc.jyu.fi

T. Piirainen, Entomological Society of Tampere, Kaarilahdenkuja 11, FI-33700 Tampere, Finland

Received 28 May 2004, accepted 30 September 2004

\section{Introduction}

In 2002, adult flies were collected from two springs in Viidumäe Nature Reserve, Saaremaa Island, Estonia. A total of 15 moth fly taxa (Diptera: Psychodidae) were determined, including a new species beloning to genus Lepimormia Enderlein, 1936. In this paper, the species is described and its affinities to other members of the genus are discussed.

Ježek (1984) has confirmed the status of Lepimormia as a valid genus. The distinguished morphological characteristics for the genus are, for example, pedicellus without a strong protuberance laterally; neither third nor fourth segments of antennae conspicuously enlarged; sensory filaments of the flagellar segments in the shape of a comb with bent base; circular organs (porthole/bull eye organs) of the antennal seg- ments 4-8 developed. Lepimormia is a rather small genus, six species are known from the Holarctic region (Ježek 1994a).

\section{Material and methods}

The studied insect material was collected by Malaise traps, two traps in a spring fen (Kanna) and two other ones in a nearby spring brook (Nakimetsa). Ethylene glycol was used as a preservative in the traps and the material was finally preserved in $70 \%$ ethanol. The traps were in the field from the middle of April to the middle of November 2002 and the traps were emptied in monthly intervals. Psychodids were later sorted out from the material and slide mounted permanently in Euparal. 


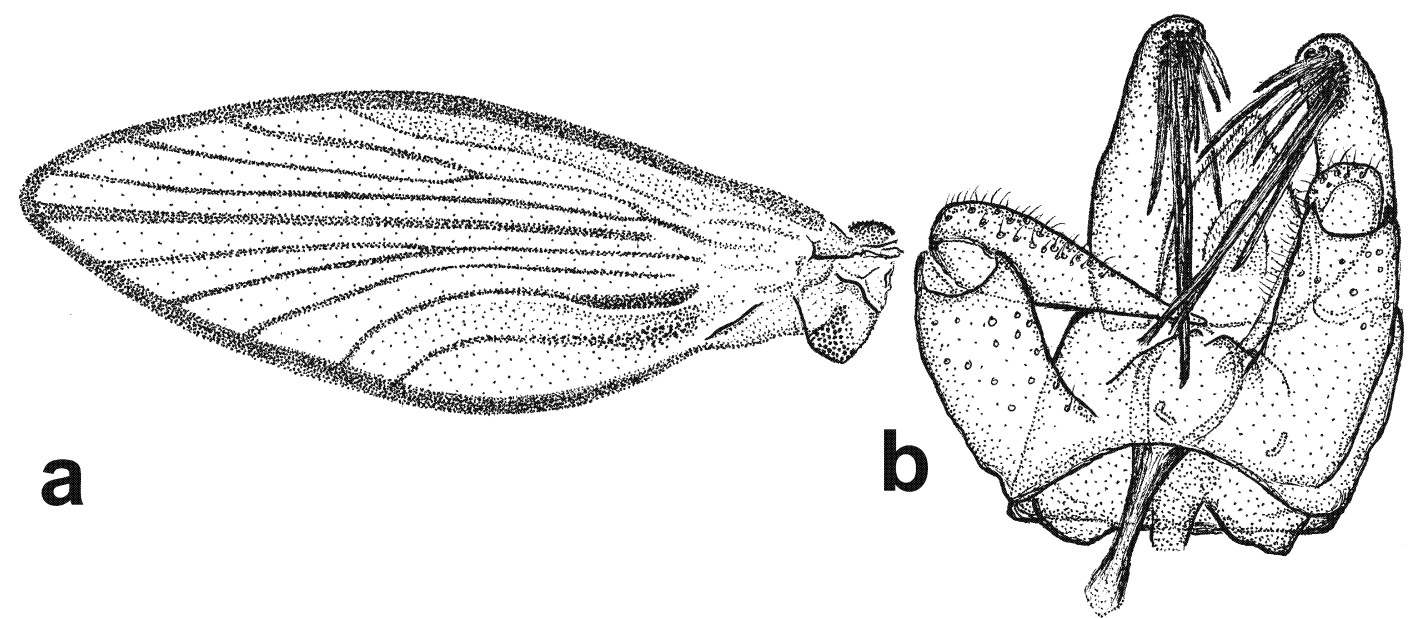

Fig. 1. Lepimormia hemiboreale sp. n. - a. Wing. - b. Hypopygium, dorsal view (holotype).

\section{Species description}

\section{Lepimormia hemiboreale sp.n. (Figs. 1-3)}

Material. Holotype $\lesssim$ : Estonia, Saaremaa Island, Viidumäe Nature Reserve, Kanna spring fen, 58 17'48” N 2205'11' E, 13.IV.-15.V.2002. T. Talvi leg. Paratypes: $19 \widehat{\partial} \widehat{\jmath}$ from the same locality. Holotype and 6 paratypes are deposited in the Zoological Museum, the University of Helsinki, two paratypes in the collection of Dr. R. Wagner,
Schlitz, and other paratypes in collection of J. Salmela, Jyväskylä.

Diagnosis. Small species, wing length 1.5$1.7 \mathrm{~mm}$. Pedicel almost cylindrical, porthole organs on segments 4-8, ascoids rake shaped. Cercopods bearing 10-13 retinaculi.

Description. Male: Head. Eyes contiguous, contact zone as long as 2 facet diameters, eyebridge consists of 3 rows of facets. Scape apically increasing in diameter, 1.9 times longer than greatest diameter. Pedicel shorter, almost cylin-

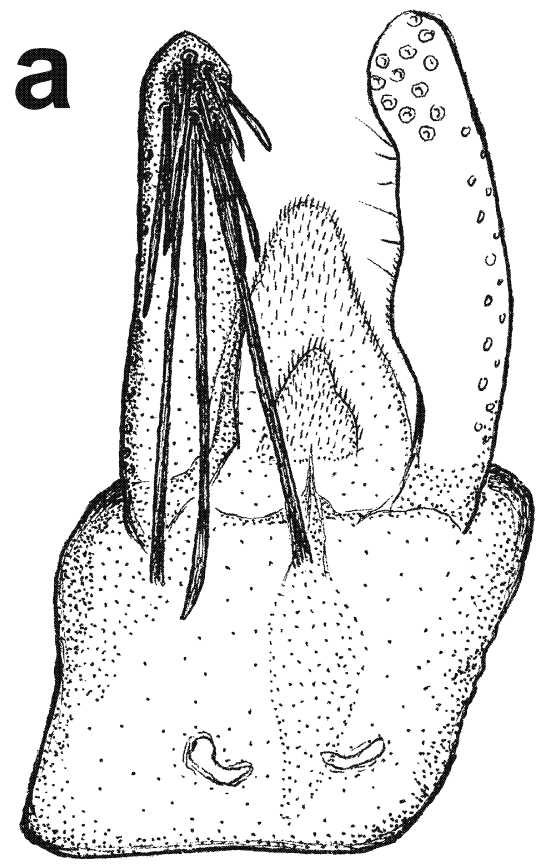

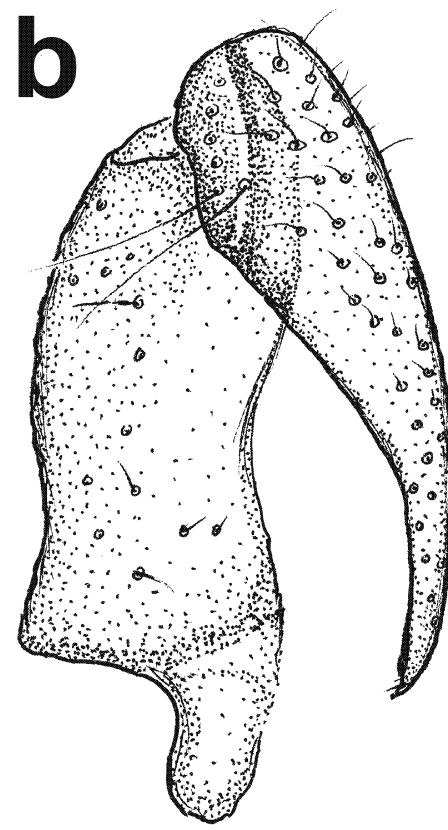

Fig. 2. Lepimormia hemiboreale sp. $\mathrm{n}$. - a. Hypandrium, dorsal view. - b. Gonocoxite and gonostylus, dorsolateral view. 
Fig. 3. Lepimormia hemiboreale sp. $\mathrm{n}$. - a. Aedeagus, dorsal view. - b. Cercopod, lateral view.

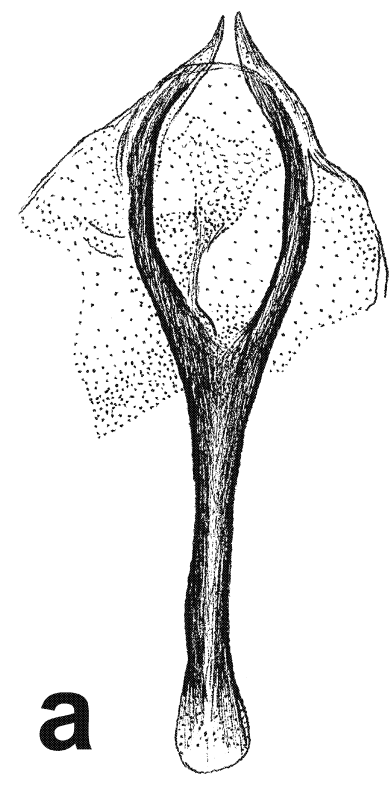

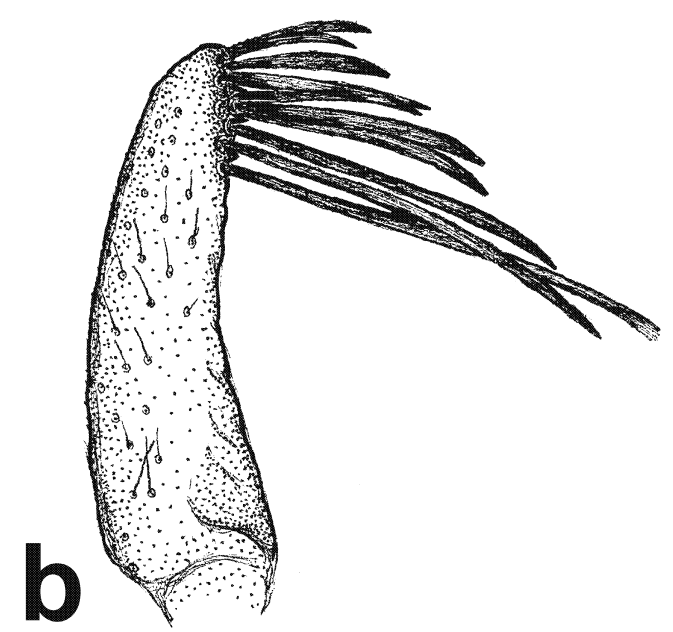

drical. Flagellar segments flask shaped, porthole organs on antennal segments 4-8. Segments 3-8 each with rake-shaped ascoid. Length ratio of antennal segments $1-9$ : 40; 24-25; 24-27; 24 $27 ; 21-24 ; 21-23 ; 21-24 ; 21-23 ; 22$. Other segments missing. Length ratio of palpal segments: 22-26; 31-35; 29-33; 29-43.

Thorax. Coloration brown. Wing (Fig. 1a) 1.5-1.7 mm. Length/width index 2.66-3. Basic color light brown, cells $\mathrm{a}_{1}, \mathrm{a}_{2}$ and sc somewhat darker, clouded. Base of $\mathrm{M}_{4}$ thickened and sinuous, distinctly darker than distal part of the vein. $\mathrm{Cu}$ basally sinuous and slightly thickened. Sc without connection to $\mathrm{R}_{1}$.

Hypopygium (Fig. 1b). Subgenital valve (Fig. 2a) triangular, very setose in the distal $2 / 3$, pointed or slightly rounded distally. Subanal valve (Fig. 2a) setose and rounded, but shorter in length. Ventral bridge of equal thickness. Gonostylus as long as gonocoxite (Fig. 2b). For aedeagus and cercopod, see Fig. 3a-b.

Female: Unknown.

Remarks. Lepimormia hemiboreale sp. $\mathrm{n}$. is similar to other members of the genus. Lepimormia bryophila (Vaillant, 1960) has 10 retinaculi, and its 3rd palpal segment is incomplete. Lepimormia palposa (Tonnoir, 1919) and L. josanicana (Krek, 1972) both have 15-17 retinaculi and complete 3rd palpal segment (see Vaillant 1974). Lepimormia georgica (Wagner,
1981), L. sibirica (Ježek, 1994) and L. vardarica (Krek, 1982) however, are perhaps most closely related to L. hemiboreale sp. n. but the structure of the male hypopygium, especially the shape of aedeagus and subgenital and anal valves, readily distinguish $L$. hemiboreale sp. n. from these.

\section{Type locality and other recorded Psychodidae species}

The type locality is an open, eutrophic spring fen. Percolation of groundwater around the fen is moderate and only a small and slowly flowing brook runs the water from the fen. Water characteristics of the brook were measured in 14.VI.2002 and the results indicate lime rich ground water area, since $\mathrm{pH}$ was 8,07 and conductivity $414 \mu \mathrm{S} / \mathrm{cm}$.

A list of Psychodidae species of the Kanna spring fen and Nakimetsa spring brook is presented in Table 1. According to Wagner (1990) all listed species are reported for the first time from Estonia. Interestingly, Lepimormia hemiboreale sp. n. was the second numerous species in the material (together with Panimerus albifacies), outnumbered only by a common and widespread Clytocerus ocellaris. Species like Sycorax silacea, Telmatoscopus carthusianus, Panimerus albifacies, Peripsychoda auriculata 
Table 1. A list of Psychodidae from two springs of Viidumäe Nature Reserve 2002, J. Salmela det.

\begin{tabular}{|c|c|c|}
\hline Species & kimetsa & Kann \\
\hline Sycorax silacea Haliday, 1839 & - & 9 \\
\hline Clytocerus ocellaris (Meigen, 1804) & 49 & 55 \\
\hline $\begin{array}{l}\text { Clytocerus tetracorniculatus } \\
\text { Wagner, } 1977\end{array}$ & - & 1 \\
\hline Pneumia mutua (Eaton, 1893) & 2 & - \\
\hline $\begin{array}{l}\text { Peripsychoda auriculata } \\
\quad \text { (Curtis, 1839) }\end{array}$ & 1 & - \\
\hline Lepimormia hemiboreale sp.n. & - & 20 \\
\hline $\begin{array}{l}\text { Paramormia polyascoidea } \\
\quad(\text { Krek, 1971) }\end{array}$ & 1 & - \\
\hline $\begin{array}{l}\text { Philosepedon humerale } \\
\quad \text { (Meigen, 1818) }\end{array}$ & - & 2 \\
\hline Logima albipennis Zett. group & - & 1 \\
\hline $\begin{array}{l}\text { Psychoda phalaenoides } \\
\text { (Linnaeus, 1758) }\end{array}$ & - & 1 \\
\hline $\begin{array}{l}\text { Feuerborniella obscura } \\
\text { (Tonnoir, 1919) }\end{array}$ & 2 & - \\
\hline Jungiella consors (Eaton, 1893) & - & 2 \\
\hline Panimerus albifacies (Tonnoir, 1919) & 2 & 18 \\
\hline $\begin{array}{l}\text { Parajungiella pseudolongicornis } \\
\quad \text { (Wagner, 1975) }\end{array}$ & - & 1 \\
\hline $\begin{array}{l}\text { Telmatoscopus carthusianus } \\
\text { (Vaillant, 1972) }\end{array}$ & 2 & 2 \\
\hline
\end{tabular}

and Feuerborniella obscura perhaps prefer springs (Vaillant 1978). In addition, Parajungiella pseudolongicornis and Clytocerus tetracorniculatus were described from spring habitats (Wagner 1975, 1977), but both species are reported from other habitats, too (Salmela 2003).

Acknowledgements. We are deeply indebted to Dr. Tõny Talvi for collecting the material in 2002. We also thank
MSc Jari Ilmonen and PhLic Lauri Paasivirta for their help in the field work, and Dr. Rüdiger Wagner for confirming the status of the new species.

\section{References}

Ježek, J. 1984: Nomenclatorical changes of some higher taxa of palearctic Psychodinae (Diptera, Psychodidae). - Acta Faunistica Entomologica Musei Nationalis Pragae 17: 155-170.

Ježek, J. 1994a: Catalogue of Holarctic and Afrotropical Mormiina End. (Diptera, Psychodidae, Psychodinae, Mormiini). - Časopis Národniho Muzea, Řada Přirodovědná 162: 63-66.

Ježek, J. 1994b: New taxa of moth flies (Diptera, Psychodidae) from the Palearctic region. - Casopis Národniho Muzea, Řada Přirodovědná 162: 55-62.

Krek, S: 1982: Psychodidae (Diptera) Sjeverne Makedonije. - GZM (PN) 21: 147-161.

Salmela, J. 2003: New records of the families Psychodidae, Dixidae and Thaumaleidae (Diptera, Nematocera) from Finland. - Studia Dipt. 10: 143-152.

Vaillant, F. 1974: 9d. Psychodidae. - In: Lindner, E. (ed.), Die Fliegen der Palaearktischen Region 305: 109-142. Stuttgart.

Vaillant, F. 1978: Psychodidae.- In: Illies, J. (ed.), Limnofauna Europea: 378 - 385. G. Fischer Verlag/Swets \& Zeitlinger B. V. 532 pp.

Wagner, R. 1975: Sechs neue Psychodidenarten aus Deutschland und Österreich (Diptera, Psychodidae). — Mitt. Dtsch. Ent. Ges. 34: 1-9.

Wagner, R. 1977: Neue Europäische Psychodiden (Diptera: Psychodidae). — Senckenbergiana Biol. 58: 157170.

Wagner, R. 1981. Some psychodidae (Diptera) from the Southern Caucasus and Iran. - Aquatic Insects 3:4556.

Wagner, R. 1990: Family Psychodidae. - In: Soós, A. (ed.), Catalogue of Palearctic Diptera, Psychodidae. - Chironomidae, vol. 2: 11-65. Budapest. 